Maria Canellopoulou-Bottis

\title{
A different kind of war: I nternet databases and legal protection or how the strict intellectual property laws of the West threaten the developing countries' information commons
}

\begin{abstract}
:
This paper describes intellectual property legislation in the European Union, the US and the Draft Treaty on the legal protection of unoriginal databases, usually available in the Internet. I argue that this type of legislation, if enforced upon developing countries and countries in transition through international 'agreements', could in effect deprive them of their own information commons, their own public domain. With examples from China, India, Africa and Iceland, I argue that this deprivation in the case of developing countries is, morally, equal to a virtual war against them by the West, wholly unjustified and dangerous-an example of virtual imperialism.
\end{abstract}

\section{Agenda}

A few notes on the nature of databases

A forceful first attack: the European Directive on the legal protection of databases

The American efforts: bills for and bills 'against'

The WIPO Draft Treaty of 1996

The position of the developing counties

A country's information commons and control

Conclusion

Author:

Dr. Maria Canellopoulou-Bottis, Lecturer, Ionian University, Harvard Faculty Fellow, 2000-2001, Center for Ethics and the Professions

- Ionian University, Rizospaston Voulefton Ioniou Voulis, Corfu 49100, Greece

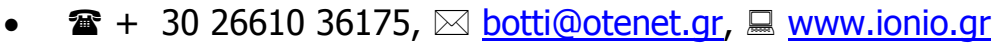


The primary function of the law used to be, and still is, up to a great point, the peaceful resolution of human disputesi. Where law was, war was noti. A second role, increasingly important as the world's countries developed after the Industrial Revolution, was to serve as a 'tool', facilitating the most efficient ${ }^{i i i}$ production and allocation of resources ${ }^{\text {iv }}$-as a road, or as an instrument. However today, if we examine the way particular laws of the West rule developing countries and how globalization proceeds, we may conclude that law is war: the West does not enter the developing countries' domains and does not typically insult their sovereignty, under pretext of some reason-casus belli, with fighter planes' attacks and soldiers, but nevertheless, the West uses law as means of war. It is not a war aiming at destroying and then owning; it is a war about complete, unsaid, subtle, control-in the name of global progress, prosperity, harmonization and equality. And if this is so, what war could be most dangerous than this one?

The war, then, of the past seems to have altered its nature. Not that 'real' wars are not fought anymorethey are-but, there is another, more dangerous war, in evolution. It is one thing to conquer and control another country's lands and seas and air and pavements-it is quite another thing, perhaps much more important in financial terms, to control another country's rights to its commons, its right to its own public domainv. Usually, the notion of the public domain, the 'information commons', in relation to information and data, is not analyzed as something every different country 'has', as part of its intangible treasure. In this article though, I will deal with the notion of public domain in relation to information, which morally, and for concrete reasons, 'belong' to this particular country and not another (just as, in terms of property, this country enjoys sovereignty over its lands and natural resources). This is about information, which under certain circumstances should 'belong' to the people of particular countries and which should not come under another country's control, because of global intellectual property rights combined with immense financial power. Indeed, such control, the 'death' of a country's information commons $^{\mathrm{vi}}$, is degrading for its people and deeply immoral. It is important to carve out what public domain is, in general and what a certain country's (developed or not) information commons is, in particular-a difficult task. But whatever 'commons' is, whatever 'public domain' is, as there have been some debates about this ${ }^{\mathrm{vii}}$, a special kind of information certainly belongs to it.

\section{A few notes on the nature of databases}

Science, business, education, economy, law, culture, all areas of human development 'work' with the constant aid of data. Databases ${ }^{\text {viii }}$ play a crucial role within science research: the body of scientific and technical data and information in the public domain is massive ${ }^{i x}$ and factual data are fundamental to the progress of science. ${ }^{x}$ But the progress of science is not the only process affected by the way people use databases. Stock exchange data are absolutely necessary to any analyst; access to comprehensive databases of large scale is an everyday activity of a teacher, an educator, an academic or a lawyer. There are databases collecting all sorts of different data: nuclear structure and radioactive decay data for isotopes (the Evaluated Nuclear Structure Data File) and genes sequences (the Human Genome Database), prisoners' DNA data ('DNA offender database $\left.^{\prime \times i}\right)$, names of people accused for drug offenses (NADDIS ${ }^{\mathrm{xi}}$ ), telephone numbers ${ }^{\mathrm{xiii}}$, legal materials $^{\mathrm{xiv}}$ and many others.

Most databases are now offered on line, so their use presupposes the use of the Internet ${ }^{\mathrm{xv}}$. Besides paying the cost of using the Internet, a cost extremely different depending on where someone lives- 0,12 for 20 hours of use for a citizen of Sweden and 33,07 for a citizen of Uruguay in 2001 (268 times more) ${ }^{\mathrm{xvi}}$-one has, some times, to pay an additional fee to enter the database-unless the database is offered in the Internet for free, or someone else has paid for the user (for example, the University for a student). As proven in part, I think, by the above disparity in numbers, access to the Internet in developing countries is limited, although growing rapidly in most of them ${ }^{\text {xvii }}$.

Whether one has or has not access to the Internet is already a kind of law, determining the use of an online $e^{\text {xviii's }}$ database by a prospective user. After this crucial, for the developing countries especially, starting point, there are other laws ${ }^{\mathrm{xix}}$, regulating how and how much one can 'take' from a database. These laws were (and still are, but not exclusively) usually contract ${ }^{x x}$ (private arrangements between the owner and the user of a database) and copyright $^{\mathrm{xxi}}$ (general arrangement of how much can be taken, under the doctrine of 'fair use'). Quite apart from these two controls, internationally there is now a trend towards privatization of information, for the benefit of database owners, who in their almost absolute majority, come from the West. ${ }^{\text {xii }}$ It comes naturally, then, that the West is the place 
where the discussion about strong database legal protection begun.

\section{A forceful first attack: the European Directive on the legal protection of databases}

After the Information Age digital revolution, and because copying in the digital world is indeed easy, the threat of piracy has lead, at least allegedlyxiii, the European Union to the adoption of a Directive ${ }^{x x i v}$ for the protection of databases. After abandoning the humble starting point of implementing a regime of unfair competition remedies $^{\mathrm{x} \times \mathrm{v}}$, in case of wholesale unauthorized copying and using in commerce of another's database, the Directive presented $^{x \times v i}$, as its most important innovation ${ }^{x \times v i i}$, a sui generis right of the maker ${ }^{\text {xxviii }}$ of a database. This sui generis right means that, its holder (the maker) may prevent the extraction and/or the reutilization of the whole or of a substantial part evaluated qualitatively and/or quantitatively, of the contents of that database (Art. 7, 1). The repeated and systematic extraction (and reading only) of insubstantial parts of the protected database is also forbidden (Art. 7, 5). As forbidden re-utilization, Art. $72 \mathrm{~b}$ defines 'any form of making available to the public all or a substantial part of the contents of a database..' and this covers the situation in which material is made available on the Internet ${ }^{x x i x}$. What is irrelevant is the nature of the information 'trapped' by the maker in her database: whether they are original works of authorship, 'entitled' to copyright protection in their own 'right', or simple 'synthetic ${ }^{\text {rxx }}$ data as telephone numbers, codes, real estate or job listings, dates of football games, radiobroadcasting listings or other data in the public domain, as the texts of judicial decisions of a country.

The Directive contains no exceptions for government-made databases, leaving European governments the options of charging citizens for the use of databases made at the public's expense and the dilemma whether such a law conflicts with the norms of an information society, offering in theory a general right to $\mathrm{know}^{\mathrm{xxi}}$ to its citizens. The Directive, also, offers no mandatory public-interest exceptions, such as usually contained in a copyright statute, of national or international application. The academic, scientific and library communities were startled to learn that exceptions in their benefit were an option for the European states ${ }^{\mathrm{xx} x i i}$ and that, moreover, no allowance was made for the re- utilization of data-a normal and absolutely necessary scientific activity. The Directive plainly forbids, in essence, the re-utilization of data from a protected database, even for scientific purposes. And the usual 'fair use' copyright exception (or some form of it), which these communities already used at their peril, simply was no more. An older article, allowing compulsory licenses to data, in cases of abuse, was in the end completely eliminated. The sui generis right 'life' was 15 years, however, database updates equally extend the protection-practically, forever.

The Directive suffered important criticism from almost the very beginning; both imminent $\mathrm{EU}^{\mathrm{xx} \times \mathrm{xii}}$ and US ${ }^{\mathrm{xxxiv}}$ scholars wrote 'dreadful' things about it, or at least were firmly positioned against it. The main arguments against were, mainly, that a. there was no problem to solve (danger from database wholesale piracy) $b$. the Directive was not a solution to the alleged problem $c$. the Directive enforced intellectual property kind protection to data, something which was inappropriate, clashed with the history and philosophy of intellectual property laws and had never happened before e. the Directive implemented a perpetual exclusive right to data belonging to the public domain (and so, 'privatized' the public sphere, to fortify private financial interests) $f$. the Directive insults the freedom of speech and harms scientific research and academic freedom.

Nevertheless, the Directive is now fully implemented in Europe (even if many countries missed the deadline). The case-law (there was a lot of litigation-yet another problem) we have from these countries in fact confirmed the fears of the scholars who published comments etc. against the Directive; the most important cases, which reached, as a cluster, the European Court of Justice, were the British Horseracing Board v. William Hill Organization ${ }^{\mathrm{x} \times \mathrm{v}}$ and the Fixtures Marketing Limited v. Organismos Prognostikon Agonon Podosfairou (Greek case, referred ${ }^{\mathrm{x} \times \mathrm{xv}}$ to the ECJ, together with the other two Fixtures Marketing Limited filed in Sweden ${ }^{\text {xxvii }}$ and Finland ${ }^{\text {xxxiii)}}$.

On the $8^{\text {th }}$ of June, 2004, Advocate General Christine Stix-Hackl issued her Opinion ${ }^{\text {xxxix }}$, after the extensive hearings on the matter some moths before. The Opinion fully justifying the fears of the opponents of the Database Directive. The cases were, in essence, cases where Fixtures Marketing Limited, the organizer of English football matches, claimed (in fact) ownership of the fixtures lists, because of database right, so sued to forbid the free use of the dates/games/times and places of the games 
information by various national betting agencies. The betting agencies had alleged that they had not obtained the information from the Fixtures'database itself, but from public sources, such as the newspapers etc, that their use was insubstantial and that a database, which was in essence a 'spin-off' of Fixtures' activities (a by-product of investment not primarily aimed at its production, but at the organization of the games itself), did not qualify for protection under the true meaning of the database Directive; in order to encourage and protect investment in databases, there was no need to enforce a law in the case where a database would be created at any event, like the Fixtures'lists.

Advocate General Stix-Hackl firmly rejected all arguments against database protection under these circumstances and proposed (influentially, of course), inter alia, that $a$. it is irrelevant whether a database is 'a spin-off' or not b. that indirect extraction of data, which also happen to constitute part of a a database from publicly available sources, is also forbidden c. the term 'database' is to be construed widely $d$. the databases' purpose is irrelevant as to its protection and e. the term 'obtaining data through substantial investment' is not the same as the creation of data, but when creation coincides with collection and verification then the condition of 'obtaining though substantial investment' is fulfilled. Lastly, and very importantly, dynamic databases (those which are updated usually) are protected as a whole for the Directive's 15 years term (in fact, forever, as most of them are constantly updated), and no new time limit starts for every new addition of data in the database. It is indeed hard to imagine an interpretation of the Directive, which could better justify its criticism or stronger protect the database producers' interests. Until the end of the year, we expect the European Court of Justice's final ruling, but Opinions by General Advocates re influential-there is no substantial reason to expect a deviation from this Opinion at this particular moment.

\section{The American efforts: bills for and bills 'against'}

Soon after the European Directive was enacted, intense pressures in the States lead to the deposition of a (first) bill for the protection of databases, HR3531, the 'Database Investment and Intellectual Property Antipiracy Bill' of 1996. The 'unkind' reciprocity clause of the European Directive, that databases were to be protected in European territories as far as the country of their origin provided for the same protection as the Directive, was a constant argument of the bills' favorers, noting also the alleged gap of protection left by Feist ${ }^{x i}$. This first bill, drafted after a strong exclusive rights model, aimed at enforcing a sui generis right, on databases, which would be the result of a quantitatively or qualitatively substantive investment of human, technical financial or other resources in the collection, verification, organization or presentation of the database contents ${ }^{\text {xlii. }}$. Protection lasted for 25 years (ten more than the European Directive's term of protection). No exception for fair use or fair dealing existed in the bill, which also prohibited the importation, manufacture or distribution of any device that had as its primary purpose or effect the circumvention of database protection systems (this was also not included in the Directive). All contractual provisions stood as such, as there were no minimum rights for users and all other regimes possibly protecting databases stood as well, untouched by the bill.

There was intense opposition against the bill, especially from the academic and scientific worlds 'xiii'. Soon another bill followed, HR 2652, 'The Collections of Information Antipiracy Bill of 1997', which was slightly different from the first one, and modeled closer to an unfair competition approach. In 1999, another bill was introduced, HR 1858, 'The Collections and Information Antipiracy Bill' of 1999 (HR 354), in opposition to which the communities opposing strong database protection introduced an alternative bill: The Consumer and Investor Access to Information Bill of 1999 (HR 1858). The alternative bill proposed a right to prevent the sale or distribution to the public of a duplicate of a database in circumstances where the sale or distribution was in competition with that other database. The alternative bill also contained broad exceptions for scientific and other related purposes. There was no question that this minimalist protection would never satisfy the demands of the database publishers, urging for strong protection. All these bills just lapsed.

The latest (February 2004) opposing bills are HR3261, 'Collections of Information Antipiracy and HR3872, 'The Consumer Access to Information Act 2004. HR 3216 is a 'classic' pro-protection bill, which supposedly has faced the criticisms of the interested communities (but in essence, it has not) and HR3972 is a (second) bill of good faith, supported by the academic and library communities. It contains only five paragraphs, and it prohibits in essence, the misappropriation of the contents of a database. The act is recognized as a practice which 
causes market confusion, under par. $5(a)(1)$ of the 15 USC 45(a)(1). The value of the misappropriated information must be crucial, as time-sensitive and its use by another person equals to the free riding of another's efforts. The parties must be in direct competition and the act must reduce so much the incentive to produce the database in question, so as to threaten its existence or quality. There is no right for a private suit; the bills' execution rests with the Federal Trade Commission (sec 4b). It is given that no consensus is going to be achieved, due to the vast difference between the proposed bills of the two sides of this important debate.

This American debate started from a sui generis right and ended with the proposal for an unfair competition approach-both unacceptable to those who fight against new legislation. Therefore, in the States, the course was opposite to the one in Europe, where a humble unfair competition regime was transformed into a strong exclusive sui generis right to data (per se, as proved by the Stix-Hackl Opinion of $\left.2004^{x \text { liv }}\right)$. But we do not know today what will happen with the proposed bills and what will be the effect of the final decision of the European Court of Justice, if the Court will, as expected, accept the Stix-Hackl interpretation of the Directive (which is highly probable, as no voice in Europe as powerful as the voice of the US Academies has been raised against the Directive or against this particular interpretation of its rules). It could go both ways in the US; one, supporting that if the European Court of Justice 'sees' the sui generis right as so strong, then 'reciprocal' legislation, able to protect the interests of US publishers in Europe, has to be at least comparable ('feeble' protection will do no good); or, as the worst fears (rights in pure data) of the database legislation opponents will have been realized, it is equally 'crazy' to insist on offering same protection in the US (and so, 'please drop the entire discussion'- highly improbable as well).

\section{The WIPO Draft Treaty of 1996}

In November 1996, soon after the adoption of the European Directive, a Draft Treaty for the protection of databases was put to the Diplomatic Conference of WIPO ${ }^{\mathrm{xlv}}$. The date of the document marks also its substance; it comes not only after the European Directive, but also after the first bill presented in the States for the protection of databases. In essence, the Draft Treaty is the same as these two instruments; for example, the definition of a database is as broad as the Directive's ${ }^{x / v i}$. The Draft Treaty incorporated a sui generis right approach ${ }^{\text {xlvii }}$, containing two alternative proposed terms of protection (Art. 8), for 15 or 25 years. Any substantial change to the database, evaluated qualitatively or quantitatively, including substantial change resulting from the accumulation of successive additions, deletions, verifications, modifications in organization or presentation or other alterations, which constitute from such investment, would qualify the database resulting from such investment for its own term of protection (Art. 8, par. 3). It is easy to notice at the outset that clearly, any new substantive investment in the database means a new term of protection for the whole of the database, and not (only) of the new material. Therefore, the Draft Treaty was explicit in aiming at the implementation of a perpetual protection of databases-no matter what their contents may be (for example, pure facts). So, one may argue emphatically how extremely long the term of protection of 15 or 25 years is, while in fact, the Draft Treaty meant a protection forever. On exceptions, individual countries were allowed in theory to provide for exceptions and limitations to rights, but not if these exceptions and limitations conflicted with the normal exploitation of the database or unreasonably prejudiced the legitimate interests of the rightholder ${ }^{\text {xviii. }}$ The obvious vagueness of the wording of these limitations means that the individual countries would not be able to ascertain when an exception they would wish to implement could clash with the above provisions.

\section{The position of the developing counties}

The Draft Treaty never matured into a Treaty. The overwhelming majority of comments on the draft was against it, especially in the US, where the debate on the proposed bills had already begun. The developing countries were also very concerned; there were reports ${ }^{\mathrm{xlix}}$ on the economic impact of a special legislation protecting unoriginal databases, supporting that the developing countries would be harmed by any new legislation. For example, the study on China, which is detailed and full of empirical evidence, clearly concludes that the new legal protection for unoriginal databases means that one would always have to pay for facts and that freedom of speech and thought could be seriously restricted ${ }^{\mathrm{li}}$ and it also means a decrease of data entering the public domain ${ }^{\text {lii; }}$; it means that end users would need more time and license fees to obtain useful information ${ }^{\text {liii; }}$, that 'piracy' of Chinese databases (of Tongfand and Yinghua) by many websites did not generally bring direct economic 
success to the party responsible for the infringement, '..who just published these pirated materials on their rarely visited homepages or websites for free access..none of them made profits by pirating other persons' materials..the strict protection provided by the Treaty would deter them from so doing.. .iv; that the lack of provision in the Treaty for library, research and education exemptions supported an extremely bleak view of how members of the academic and research community and the public will access information resources in the future ${ }^{\mathrm{lv}}$; and that the new legislation would increase the costs of China's college education, which is already very expensive ${ }^{\text {lvi }}$.

All this happens to a country in transition to a freemarket economy, which is advanced in its technological capabilities ${ }^{\text {Ivii. }}$ But developing countries and countries in transition are far from homogenous and they vary immensely in their social and economic structures and their inequalities in income


unoriginal databases, and in effect 'closing' the public domain and privatizing facts, which were always supposed to be 'free as the air to common use $^{\text {hix }}$, is bound to be much harder in countries which do not have any distinct benefits of technological capacity and suffer enormously, from the financial (among others) point of view. These are the developing countries, which can only be database users and not makers ${ }^{\mathrm{Ix}}$; the countries, which are mainly consumers and importers and not producers or exporters ${ }^{1 \times i}$. In these cases-and they are many-it is almost irrational to speak of the need of intellectual property laws as incentives, as tools, towards a greater production of, say, inventions, literary works, or more modern works such as on line databases ${ }^{\mid x i i}$. The need to stimulate production through incentives is the main argument for intellectual property, as we know it. Instead, what a stronger intellectual property regime means for these countries is an increase in costs of obtaining new foreign technology necessary to meet their national economic development objectives ${ }^{\mid x i i i}$. 'Tighter intellectual property protection only strengthens the monopoly power of large companies that are based in industrialized countries to the detriment of developing countries. ${ }^{\text {Ixiv }}$. And the increase in costs results in a further widening of the gap in access to scientific knowledge ${ }^{\mid x v}$.

\section{A country's information commons and control}

The question of access to scientific knowledge and to databases now absolutely necessary to any meaningful research is not the only issue, though, alerting scientists all around the world. Another distinct question is who exactly will have the 'control' of facts, once these have been made part of a protected, by intellectual property laws, database. Returning to the matter of a country's information commons, one wonders whether it is indeed moral for the developed world to press ${ }^{\text {Ixvi }}$ developing countries and countries in transition into international agreements of dubious benefit to them ${ }^{\text {Ixvii }}$ (TRIPS is an obvious example here) and then let its own enterprises make, inter alia, databases on this country's traditional knowledge, for example, 'lock' the contents of the databases through database protection laws (lasting in effect forever-remember Advocate General Stix-Hackl's opinion in the EU ${ }^{\text {Ixviii }}$ ) and therefore, controlling this country from access to information which may very well 'belong' to it. One can easily imagine, I think, a company as giant as Reed Elsevier starting business for example in Egypt, compiling large legal databases with all the judicial decisions and the laws of Egypt included and presented most efficiently. Egyptian companies may not be able to compete with this; certainly, no Haitian entities could (if we were talking about Haiti) and no companies in most developing countries could either. If this is possible and if Egypt had adopted, say because of an international WIPO Treaty on databases, a protection as strong as the European Directive's, then people from Egypt could forever be obliged to pay for access to their own jurisprudence, to facts free in theory for the taking by anyone $e^{\text {lxix }}$-and especially, from a moral point of view, by an Egyptian.

It is true that relevant concerns have been raised; for example, in an influential and frequently cited Report ${ }^{1 \times x}$, the UK Commission on Intellectual Property Rights (CIPR) stated in 2002 that developing countries may not be sharing appropriately in the benefits from commercialization of their ${ }^{\text {txi }}$ knowledge or genetic resources when they are patented in the developed countries; also, that most developing countries have genetic resources and traditional knowledge that are of value to them. Vadrevaldxxii, in his Report for WIPO on India and databases emphatically stressed that Indian 'traditional knowledge' is a sector of tremendous financial potential. 'Owing to India, being one of the most ancient civilizations in the 
world, it has tremendous reserves of traditional knowledge such as traditional medicinal knowledge, folklore, art etc.. ${ }^{\text {lxxiii }}$ Vandrevala noted that the Indian government had compiled a Traditional Knowledge Digital Library (TKDL) program and that a sui generis regime could protect its unoriginal aspects $^{\text {Ixxiv }}$. Vandrevala, lastly, also referred to Indian genomic databases, containing genomic data from a country with one fifth of the world's population, were possibly half of the world's genetic mutations occur $^{\mid x x v}$. Braunstein ${ }^{1 \times x i}$, in his Report on the economic impact of database protection in developing countries, offered as an example of a database worthy of protection the database with African alphabets by Saudi Mafundikwa, the director of the Zimbabwe Institute of Vigital Arts. Mafundikwa's database contains symbols, scripts and signs used in a number of African languages. Braunstein $^{1 \times x v i i}$ also refers to the question of the database of genetic information of the Icelandic people (rights to this database belong to the firm deCODE $\left.{ }^{\text {Ixxviii }}\right)$.

It is, indeed, a crucial point whether a country has 'a right to its own', and that within 'it's own' one may enumerate information and facts such as those concerning people's genetic data, legal opinions by its courts ${ }^{\text {Ixix }}$, traditional knowledge and such. A lot of research is necessary, I think, in order to articulate a clear theory why particular facts and information should belong to a country, just as its mountains belong to it. But we have evidence that the above classes of information should probably belong to a country's information commons, in the sense that it is immoral for another country (especially a developed one) to take away the developing country's control over 'its own'.

What Vandrevald ${ }^{1 x x}$ and Braunstein ${ }^{1 x x x i}$ may perhaps have missed, in their discussion, is that what is now controlled by the Indian government (case: Indian traditional knowledge database) or by an African prominent researcher (case: African alphabets) and what may, therefore, seem at the outset as worthy of special protection in their benefit, may very well tomorrow belong, in terms of rights, to a company of another, developed country (or not ${ }^{\text {lxxii }}$ ). An American researcher, generously funded by a US grant, may 'lock' the African alphabets into a protected database, and control the access of those who are entitled to it in Africa, just as an American company may set a subsidiary in Brazil and start 'locking' Brazilian traditional knowledge into yet another database. If the legal protection of unoriginal databases in the African country or in Brazil is similar to the European Directive's, then the contents of these databases will forever belong to its rightholders, under the minimal requirement of a usual update and, moreover, under the Stix-Hackl's interpretation, no one-Indian, African, whatevermay by herself use information which happen to be parts of a protected database, no matter where one obtains this information.

The case of Iceland's genetic information is a clear example of the immorality of a country's information (mis)appropriation. As Iceland had meticulous medical records, dating from World War I and stored DNA samples since, in 1996 a professor at Harvard Medical School raised 12 million dollars, founded the deCODE company and asked for an exclusive license to explore the country's genetic information. A relevant bill was passed, but there were protests not only from the Icelandic Association for Ethics and Science, but also from around the world ${ }^{\text {lxxiii }}$ about the morality of the program. Except severe problems with securing true consent of 270.000 people to the use of data and with providing true confidentiality, the question of who will benefit from the project was powerfully raised as well: there did not seem to be any real benefit to the Icelanders, who nevertheless were the source of the extremely valuable information, as part of the stock $(70 \%)$ of deCODE was in the hands of Icelandic banks (not the people's) and the rest had nothing to do with Iceland. 'It is simply not believable that any significant part of the world's pharmaceutical or biological research facilities will move to Iceland..the most significant benefit for Iceland appears to be the promise of jobs created from a database that 'cannot be exported'...seems more a cruel joke thank a reality... ${ }^{\text {dxxiv }}$. Lastly, the abdication of control by the Icelanders was spotted out as in need of a very careful consideration ${ }^{1 \times x \times v}$. It follows that the genetic information of Iceland properly belonged to its public domain; even if Icelanders lacked the 12 million dollars and the technical infrastructure to carry out this project, if they wished to carry it out, this did not mean that another country had the moral justification to do it, and enjoy its fruits. DeCODE's argument that in this case, it was Iceland who had an obligation to benefit humanity ${ }^{\mathrm{Ixx} x \mathrm{i}}$, allowing the use of the data from somebody who could do it, cannot hide the company's financial interests in the project, or cover its profit orientation behind a moral 'duty to the world'. If this were indeed the case, all developing countries would be morally bound to release their information commons to the financially powerful nations, for the benefit of humanity ${ }^{\text {Ixxxvii. }}$ Quite the contrary is true: the developing counties may indeed be morally entitled, in particular cases, to 'cheat' 
and obtain access to information 'locked up' by the West and otherwise restricted to them, with selfdefense as justification ${ }^{\mathrm{lx} \times \mathrm{v} i i i}$.

\section{Conclusion}

The end of this harsh road is the end of a country's public domain; just as it has been noted, in case of the West itself, that 'all sorts of information presently unprotected-data, statutes, case-law, government information, 'expired' works etc-may disappear from the public domain ${ }^{n \times x x i x}$. But it is one thing to 'extinguish' a developed country's public domain, through apparently democratic laws, voted by the representatives of this country, and quite another to impose, in fact, the same laws upon a practically defenseless developing country.

The question 'who owns information' has usually been dealt with as a matter to be resolved between private parties-individuals. Cases have been brought to court because a plaintiff believes that a particular piece of information belongs to her and not to the defendant (for example, disputes about who is entitled to know a software program's code, who is entitled to know whether a doctor has an AIDS infection, who is entitled to use a telephone number for marketing purposes etc $\left.{ }^{\mathrm{xc}}\right)$. In private law, we have devised special mechanisms to redress inequalities of power and abuses. The more powerful entities are treated as burdened with special obligations to protect their feebler contracting parties. Those who are able to exercise undue influence over others are legally treated very strictly. Perhaps, also in view of the extended pressures towards greater database legal protection, the time has come to consider in detail the application of the same legal principles in the cases between countries.

We should determine, in particular, in which cases individual countries have the right to own and control particular pieces of (their) information. In the case of developing countries, which are technologically impaired and lack fundamentals as basic goods for survival (food; water; basic pharmaceuticals), the control by the developed world of their intangible domains of sovereignty, through the pretext of 'consensual' international agreements and laws, and by invoking the fallacious argument that (legal) harmonization and globalization is 'good for them ${ }^{\prime \times c i}$, appears at least as morally repugnant as a total war against them ${ }^{x c i i}$-an example of virtual imperialism.
Proceedings of the symposium "Localizing the Internet. Ethical Issues in Intercultural Perspective" sponsored by Volkswagen*Stiftung*, 4-6 October 2004, Zentrum für Kunst und Medientechnologie (ZKM, Karlsruhe)

' On the concept of law, see HLA Hart, The Concept of Law, Oxford University Press, June 1997.

ii Law, as a regime ordering human activities and relations through systematic application of the force of politically organized society, naturally incorporates implementation by force, this is true; however, this is not 'war', as war means in this text the implementation of what one thinks is right or necessary with private forces, outside a legal system.

iii On efficiency, as a concept used in the economic analysis of law, see Posner $R$., Economic Analysis of Law, 1986, Little, Brown and Company.

iv And other areas-contract, property and tort have been subject to the analysis from the perspective of economics, see Kronman \& Posner, The Economics of Contract Law, Little, Brown and Company, 1979, Ackerman B., Economic Foundations of Property Law, ed. 1975, Rabin R., ed., Perspectives of Tort Law, 1976. Besides, corporation law is what I primarily had in mind, when speaking of law as a 'road' or instrument towards efficiency.

${ }^{v}$ Note the dual nature of public domain as seen by Lessig, Open Code and Open Societies, Keynote address, Free-Software-a Model for Society? June 1, 2000, Tutzing, Germany, http://cyber.law.harvard.edu/cc, p. 6: '...now among commons, among public domains, we might distinguish two categories. We might think about the public domain of real things, and the public domain of intellectual things. The public domain, for example, of streets and parks, and the public domain of ideas or created works. These commons serve similar functions but they are importantly different..'.

${ }^{v i}$ For a detailed analytical account of the commons concept as an emanation of freedom, especially in the Internet communications, see Cahir, The Information Commons, working draft of $23^{\text {rd }}$ July 2003 on file with the author, pp. 1-47.

vii See National Research Council, The Role of Scientific and Technical Data and Information in the Public Domain, Proceedings of a Symposium, 2003 and Benkler, Free as the Air to Common 
Use: First Amendment Constraints on Enclosure of the Public Domain, N.Y.U.L.Rev. 74, 354, 356 (1999), '..information is in the public domain to the extent that no person has the right to exclude anyone else from using the specified information in a particular way. In other ways, information is in the public domain of all users are equally privileged to use it...', at 360 . See also detailed analysis of what the public domain is in Litman J., The Public Domain, 39 Emory L.J. 965 (1990), who described public domain as a commons, that includes those aspects of copyrighted works which copyright does not protect., id. at 975 . The notion of 'public domain' has also been (unfairly, I think) dismissed, Samuels, The Public Domain in Copyright Law, (1993) 41 Journal of the Copyright Society 137.

viii The term 'database' is standard in legal discourse; a better term is, I believe, 'information system', as database has come to signal everything, from a website to a list of telephone numbers. On the term 'information system' see Brown M., Bryan $R$. \& Conley J., Database Protection in a Digital World, 6 Rich.J.L.\&Tech.2, (Symposium 1999), http://richmond.ed/jolt/v6i1/conley.html, part II, The Nature of Databases.

ix National Research Council, The Role of Scientific and Technical Data and Information in the Public Domain, Proceedings of a Symposium, 2003, preface, $v$.

x See generally, Reichman $J H$ \& Uhlir P., A Conceptually Reconstructed Commons for Scientific Data in a Highly Protectionist Intellectual Property Environment, 66 Law and Contemporary Problems 315 (Winter-Spring 2003), hereinafter Reichman \& Uhlir, Reconstructured Commons, id.

${ }^{x i}$ DNA Act, 42 USC 14135, 2000.

xii Narcotic and Dangerous Drugs Information System, US federal database.

xiii Feist Publications v. Rural Service Co., 499 U.S. 340 (1991).

xiv LEXIS/NEXIS, or West legal databases, examples from the Western world, also see 'Collection of China's Computer Laws', Zheng Shengli, The Economic Impact of the Protection of Database in China, WIPO Standing Committee on Copyright and Related Rights, Seventh Session, Geneva May 13 to 17, April 22, 2002, p. 31.

xv China, for example, has online databases of legislation and policies ( $11 \%$ of the total), of financial and stock information (2\%), of scientific and technical information (15\%), of newspapers and periodicals (12\%) and products (60\%), http://www.cnnic.gov.cn/tj/2.shtml - 2.1.4, see also footnote n. 11 . Wolters Kluwer, a leading multinational publisher and information services company offers electronic databases in sectors as health, tax, corporate, financial services, legal and regulatory and education and operates across Europe, North America and Asia Pacific, see Annual Report 2003, p. 5. Reed Elsevier, another world leading publisher and information provider, with principal operations in Europe and North America, offers electronic databases in the science and medical sector, legal, education and business fields, and others. Wolters Kluwer and Reed Elsevier are private; many electronic databases are governmental, with data collected, organized and maintained through the use of taxpayer's money, in different countries.

xvi As a percentage of GDP per person, see Lopez, The Impact of Protection of Non-Original Databases on the Countries of Latin America and the Caribbean, SCCRR/8/6, Oct. 15, 2002, http://www.wipo.int/, p. 10, Table A3, p. 3 of the Appendix.

xvii CIPR, Integrating Intellectual Property Rights and Development Policy, London, September 2002, ch. 5.

xviii There are many off line databases for sale, but by far the most important are the dynamic, constantly updated, on line databases.

xix And besides these other laws (contract and copyright), we must keep in mind the technological capabilities of software codes, disallowing access to the contents of a databasecodes, whose circumvention has, in the US and Europe been outlawed, threatening very severe penalties (Digital Millennium Copyright Act, US; comparable measures for the EU). This is why Lessig, id, refers to 'codes' as laws, '..we should understand code as kind of law, because code can restrict or enable freedoms in just the way law should....in the anticircumvention provision of the DMCA, Congress has turned my metaphor into reality...', p. 9.

${ }^{x x}$ See how contract was stronger than copyright in the controversial decision ProCD v. Zeidenberg, US Court of Appeals, Seventh Circuit, 86 F.3d 1447 (1996). In this case, Judge Easterbrook held that a shrink-wrap (contractual) license to use an electronic database (the terms of which license 
were not known to the buyer of the box with the database CDs in it before he bought it) was enforceable against the buyer, irrespective of copyright law (under which, the copying of the database's material-3.000 telephone numbers-was legal, as the database was not original enough to deserve copyright protection).

${ }^{x \times i}$ In the US, copyright does not cover unoriginal databases (see Feist, id, footnote 11); databases containing data in the public domain (for example, telephone numbers, scientific data, names of roads, texts of legal decisions etc.) are usually compilations not original enough to deserve copyright protection (but, under Feist, id, footnote 13 , in the US, the standard of originality is quite low). In Europe, the rules of copyright on databases are mainly contained in the Directive on the legal protection of databases, which is now implemented in all European countries. The wellknown fair use exception is not part of the Directive.

xxii Major database rights lobbyists are Reed Elsevier and Thomson publishing, giant West world corporations, see, among may others, Zittrain J., New Legal Approaches in the Private Sector, in National Academies, The Role of Scientific Data, as above, p. 169, 171, footnote 3 . See also http://www.ala.org/ ('who is pushing for database protection').

xxiii See the Directive's (many) Recitals. However, there had been no real problem with database piracy in Europe before the implementation of the Directive (virtually only one case in the Netherlands-see http://www.ivir.nl/).

xxiv Directive 96/9 European Parliament and the Council of 11 March 1996 on the legal protection of databases, 1996 O.J. (L77)2.

$x \times v$ See the first version of the sui generis right in (unoriginal) databases of Art. 2 (5), First Draft, Directive on the legal protection of databases, which was a right of the maker of a database to prevent the unauthorized extraction or reutilzation from a database, or its contents, in whole or in substantial part, for commercial purposes. The right was, then, limited to 'unfair extraction', and 'unfair' meant then, a use for commercial purposes (this right could perfectly cover the case, for example, of ProCD $v$. Zeindenberg, footnote 20, and no need to seek protection from contract law would then accrue).

xxvi Art. 7(1) of the Directive. xxvii The Directive also contains provisions, before the sui generis right, on copyright protection of the original (in the selection of arrangement of the material- the author's own intellectual creation) databases, but the significance of these provisions, in front of the extremely stronger protection of the unoriginal databases with the sui generis right, is almost 'extinguished'. No database producer would care to prove originality etc, when it is, in fact, less effectively protected and when 'substantial' in investment, to give rise to the sui generis right, has been accepted so easily.

xxviii Note how 'the author', a classic notion of the intellectual property world has now disappeared and has been replaced by 'the maker', whose definition is now the person (legal, natural) who has spent substantial investment (human, technical, financial) in creating a database, Recital 41, Directive ('the maker of a database is the person who takes the initiative and the risk of investing..'). It is difficult to justify protection of intellectual property type, traditionally rooted in the cause of rewarding creativity and thereby, stimulating production of intellectual works, where the rightholder is a maker and not an author.

xxix See detailed analysis in Davison M., The Legal Protection of Databases, Cambridge University Press, 2003, p. 88-89. On the Directive's implementation in Europe see also B. Hugenholtz, 'Implementing the Database Directive', in: Jan J.C. Kabe/ and Gerard J.H.M. Mom (eds.), Intellectual Property and Information Law - Essays in Honor of Herman Cohen Jehoram, The Hague/London/Boston, p. 183.

${ }^{x x}$ Such have been very expressively and accurately called the data which one makes and does not find in nature (for example, a telephone number or the date/time/place of a film's show or the date/time/place of a football match), see Maurer et al., Europe's Database Experiment, (2001) 294, Science's Compass 789-790. In the case where the one who makes the data is also the only one who makes them (for example, a telephone company with a monopoly over a certain territory, or the organizer of the English soccer games who produces the games' fixture lists), then we have a sole source provider of synthetic data, which no one can obtain from anywhere else.

xxxi Note, for example, how the Directive on freedom of environmental information, under which European citizens have the right to access 
environmental information, certainly clashes with the Directive on database protection in relation to the (free?) access of citizens to environmental data 'trapped' in a governmental database. Council Directive 90/313/EEC, 1990.06.07, Freedom of access to Information on the Environment. Austria was the first European country to enforce in practice the protection of governmental databases, when it sued a citizen for the use of the country's company registry and asked for a fee for this use, see ADV Firmenbuch, Austrian Supreme Court (Oberste Gerichtshof), 9 April 2002. The argument that there is a copyright exemption for governmental information, allowing free use, was rejected because of the database Directive; the defendant ordered to pay a (reasonable) fee. So now, in Austria: permission needed, reasonable payment necessary, to access public domain, taxpayers' funded, information. Same, essentially, solution by the Icelandic Supreme Court, Hoyesterett, 19 September 2002, where a citizen used data (aerial lines, water and roads data) from maps bought by the State Geographic Institute and made new maps, to sell in commerce. Copyright exemptions allegations overruled. See http://www.ivir.nl/, 'the database rights file'.

xxxii Which Greece, France and Italy, lamentably ignored altogether and other countries interpreted differently. See (amended, to incorporate the Directive's provisions) L. 2121/1993, for Greece and Book II, Intellectual Property Code 1992, for France and for Italy, see Law on Copyright and Neighboring Rights 1961, as amended, n. 633 of 22 April 1941. So much for uniformity as the purpose of European Directives.

xxxiii See as examples, Cornish W., 1996 European Community Directive on Databases (1996) 21 Columbia-VLA Journal of Law and the Arts, $1, \underline{P . B .}$. Hugenholtz, 'Program Schedules, Event Data and Telephone Subscriber Listings under the Database Directive. The 'Spin-Off' Doctrine in the Netherlands and elsewhere in Europe', paper presented at Eleventh Annual Conference on International IP Law \& Policy, Fordham University School of Law, New York, 14-25 April 2003, Stephen M. Maurer, P. Bernt Hugenholtz \& Harlan J. Onsrud, 'Europe's Database Experiment', Science, vol. 294 (26 October 2001), p. 789-790, P.Bernt Hugenholtz, 'Code as code, or the end of intellectual property as we know it', Maastricht Journal of European and Comparative Law, Volume 6 (1999), No. 3, p. 308-318 (a more general account on intellectual property matters), Davison M., id., Koumantos G., Les Bases des Donnes dans la Directive Communautaire, RIDA 1997, 85, Adams J., 'Small Earthquake in Venezuela': The Database Regulations 1997, EIPR 1998, 2004), 129-134, Colston C., Sui Generis Database Right: Ripe for Review? 2001, 3 JILT.

xxxiv Reichman $J H$ \& Samuelson P., Intellectual Property Rights in Data? Vanderbilt L.R. vol. 59, no 1, January 1997, pp. 51-166 (a seminal account and standard text), Reichman \& Uhlir, Reconstructured Commons, id. National Research Council, Bits of Power: Issues of Global Access to Scientific Data, National Academies Press, Washington DS, 1997. Band J., Testimony of Jonathan Band on Behalf of the Online Banking Association before the Subcommittee on Courts and Intellectual Property of the United States House of Representatives Committee of the Judiciary on the 'The Collections of Information Antipiracy Bill of 1999 , HR 354, $106^{\text {th }}$ Congress. Testimonies of experts in hearings for the various US bills on database protection, who were posed against new legislation, or for a limited type, typically contain rejection of the European Directive. http://www.house.gov/.

xxxv HC 2000, 1335, judgment of February 2001.

xxxvi Reference for a preliminary ruling by the Monomeles Protodikio Athinon by order of that Court of 11 July 2002 in the case of Fixtures Marketing Limited against Organismos Prognostikon Agonon Podosfairou $A E$, Case C444/02, (2003/C 31/17), Official Journal of the European Union C 31/12, 8.2.2003.

xxxvii Fixtures Marketing Ltd v. AB Svenska, Spel, T 99-99, 11 April 2001.

xxxviii Vantaan Karajaoikeus (District Court, Vantaa), $1^{\eta}$ Фعßpouapiou 2002, (Case C-46/02) (2002/C 109/46), OJ 4.5.2002.

xxxix Press Release n. 46/04/EN-full text in the Opinion of Advocate General Stix-Hackl in Cases C-46/02, C-203/02, C-338/02 and C-444/02, Fixtures Marketing Limited v. Oy Veikkaus, The British Horseracing Board Lts and Others v. William Hill Organization Ltd. Fixtures Marketing Ltd. v. Svenska Spel AB, Fixtures Marketing Ltd v. Organismos Prognostikon Agonon Podosfairou (OPAP), see http://www.curia.ru.int/

$x \mathrm{l}$ The 'spin-off' argument had been successful in lower European courts, and is a totally reasonable argument: the aim of the Directive was to protect 
a database, which was the result of substantive investment, not a database which would be produced anyway, as a by-product of other activities. That Fixtures Limited wants to share some of the enormous profits of national betting agencies is of course understandable from a pure financial point of view, but this was simply not the kind of database which was in danger of elimination from piracy, should a law as the Directive not 'rush' to 'save' it.

xli Id.

xlii Section 3(a) of the bill.

xliii See, e.g. National Research Council, Bits of Power, Issues of Global Access to Scientific Data (National Academies Press, Washington, DC, 1997), pp. 157-160.

xliv See above, p. 8.

xlv Basic Proposal for the Substantive Provisions of the Treaty on Intellectual Property in respect of Databases considered by the Diplomatic Conference on Copyright and Neighboring Rights Questions, Geneva, December 1996, CRNR/DC/6.

xlvi Draft Treaty, Art. 2.

xlvii The act of 'extraction' was the 'permanent or temporary transfer of all or a substantial part of the contents of a database to another medium by any means or in any form', while the act of 'utilization' was the making available to the public of all or a substantial part of the contents of a database by any means, including the distribution of copies, by renting, or by on-line or other forms of transmission, including making the same available to the public at a place and at a time individually chosen by each member of the public. A substantial part was any portion of the database, including an accumulation of small portions, which is of qualitative or quantitative significance to the value of the database.

xlviii Art. 5. The protection of governmental databases was left to the states' discretion.

xlix WIPO commissioned in 2001 five studies on the economic impact of the protection of non-original databases in developing countries and countries in transition. Reports were therefore filed in April 2002 by Yale Braunstein, Economic Impact of Database Protection in Developing Countries and Countries in Transition, 4 April 2002, SCCR 7/2, Sherif El Kassas, 'Study on the Protection of Unoriginal Databases, 4 April 2002, SCCR 7/3, Thomas Riis, Economic Impact of the Protection of
Unoriginal Databases in Developing Countries and Countries in Transition', 4 April 2002, SCCR 7/4, Phiroz Vandrevala, 'A Study on the Impact of Protection of Unoriginal Databases on Developing Countries: Indian Experience', 4 April 2002, SCCR $7 / 5$, Shengli Zheng, 'the Economic Impact of the Protection of Databases in China', 4 April 2002, SCCR 7/6, Andres Lopez, The Impact of Protection of Non-Original Databases in the Countries of Latin America and the Caribbean, October 15, 2002, SCCR 8/6.

Not all the reports came to this particular conclusion; for example, the study by Braunstein, id, sustained that the protection could benefit the developing countries. However, 'this position (Braunstein's) is based to a large extent on the application of theoretical tools developed originally for trage in goods. Unfortunately, these tools assume, among other restrictive assumptions, the absence of economics of scale, making their applicability to databases very limited...' (Lopez, id., p. 18). Also, the study on India by Vandrevala, id., contains some elements on the potential of India to commercialize governmental databases and therefore, possibly earning income by developing a database industry. But Vandrevala also points that there is a drawback of the new legislation, the problem of access to the protected works by the academic and scientific community (id., p. 29), a drawback which he proposes to address by specific exceptions for research etc. Quite another problem is, under Vandrevala, (id), that the '..psyche of the social and economic thinkers (in India) has always been against the grant of intellectual property rights...the recognition of new forms of intellectual property rights still remains a very contentious issue...'. (No proposal exists in the study to face this particular problem, not any attempt to explain why this general, as mentioned, distrust, may be wrong).

li Zheng Shengli, id., p. 44.

lii Id., p. 58, : '..Driven by the profits and under budgetary pressure, the Government will be inclined to cooperate with private entities. As a result, the data which should have been publicized by the Government is now not accessible free of charge to the public. There will be less and less data in the public domain and the information already in the public domain will be available to the public in a restrictive way..'.

liii Id., p. 46.

liv Id., p. 47, a case of 'information Samaritans'. 
${ }^{\text {Iv }}$ Id., p. 48.

Ivi Id., p. 48. '..the national average annual college costs of China is comparatively very high.. in the yeat 2000, tuition and mandatory fees, costs of room and board and total costs of American public colleges are 3,510, 4,960 and 8,470 respectively, while per capita GDP for the US is 29,326 US dollars. However, the corresponding numbers for China are about 600, 20, 620 and 780 respectively. In the US, the total costs of public colleges is about $28 \%$ of its per capita GDP; in China, the corresponding number is about $94 \%$. Therefore, Chinese students would have much less money to pay for the said license (to use protected databases) fees...', id., p. 48. The Report from Sherif El-Kassas, from the American University of Cairo, id., concludes that any new sui generis protection of database would detract from the public domain and thus significantly reduce the availability of free information and data, may create counter productive perpetual monopolies by allowing owners of databases to indefinitely expand the period of protection, will be harmful to the free flow of information in the scientific communities of the world, will be harmful to the development of the Internet and the software industry because many components of the software industry will become protected and hence will no longer be available for free use and utilization and will hamper many aspects of development in the developing and under developed world. Id., p. 10 (conclusions).

Ivii Note the rapid expansion of Internet users in China and the immense increase in the number of databases, id., p. 6.

Iviii Commission on Intellectual Property Rights, Report, Integrating Intellectual Property Rights and Development Policy, London 2002, p. 1. '..What works in India will not necessarily work in Brazil or Botswana..'.

lix See Benkler, id.

Ix For example, under the Gale Directory of Databases, cited by Braustein, id., only $0,2 \%$ of all databases in existence worldwide in 2001 came from 'Southern America' (only 21 listed, see Riis, id., p. 22, who maintains that the number is not true-'the number of the databases in the region is clearly underestimated', but also that the same is true in other regions and countries, 'the countries of Latin America and the Caribbean are much more 'importers' of databases than 'exporters', id., p. 22).

Ixi See for example, Wade R., What Strategies Are Viable for Developing Countries Today? The World Trade Organization and the 'Shrikning of Development Space', Review of International Political Economy, v. 10, n. 4, 2003, '..the North is a net producer of patentable knowledge and the South a net consumer....', p. 4.

xii Note, for example, that Haiti is not even reported as having any PC per 100 inhabitants (same for Antigua, Puerto Rico, Aruba and others. Haiti is also not reported as having any server per 10.000 inhabitants and the Internet users per 10.000 inhabitants in Haiti are 24,54-same number in the US is 4.506, 96 and Europe, 1359, 48-see Riis, id, Annex I, page 2, Table A.2.

Ixiii See Report by Riis, id., p. 19. 'In order to enjoy the full (dynamic) benefits of intellectual property protection of databases, a developing country must have an effective and wide-spread information technology infrastructure; otherwise, the incentive effect is comparatively lower in developing countries than in industrialized countries', id., p. 23. See also World Bank (2001), 'Intellectual Property: Balancing Incentives with Competitive Access' in Global Economic Prospects and the Developing Countries 2002, Washington DC.

Ixiv Riis, id., p. 19, referring to a view by Almeida (1995), The political economy of intellectual property protection: technological protectionism and transfer of revenue among nations', 10 International Journal of Technology Management, pp. 214-229. Riis's conclusions include that there is a strong case that optimal intellectual property regime in industrialized countries is not optimal is developing countries and that, in the short run, developing countries which typically are technology-importing countries will loose social welfare by enhanced intellectual property standards, because higher intellectual property standards in the long run will lead to an increase in royalty payments to foreign right owners. 'The empirical evidence that we have collected from Latin America and the Caribbean..does not seem to support the argument in favor of introducing IPRs for non-original databases, in that we have not observed that the incipient industry that exists in the region, apparently concentrated in the more advanced countries, is being damaged by the absence of sui generis legislation..', id., p. 29. 
Ixv Wade, id, p. 5, '...research libraries around the world paid out $66 \%$ more for scientific monographs in 2001 than they did in 1986 and got $9 \%$ fewer monographs for their money and paid out $210 \%$ more for $5 \%$ fewer periodicals..'.

Ixvi On the immense pressure of the US in particular towards the adoption of TRIPS, exercised upon developing countries see Shadlen K., Patents and Pills, Power and Procedure: The North-South Politics of Public Health in the WTO, Studies in Comparative International Development, vol. 39, n. 3 (Fall 2004) on file with the author. 'In the 1980s and the 1990s the developed countries led by the US pushed for stringer enforcement of a less flexible set of regulations regarding intellectual property protection. The increased prominence of IPRs in US foreign policy is a story of sectoral politics in which well-organized industry groups representing the chemical, pharmaceutical, entertainment and software industries pushed the US government to use trade sanctions against countries that were argued to be lax in protecting their copyrights, patents and trademarks...business lobbying had made TRIPS a high priority for the US in the Uruguay Round negotiations, and considerable pressure was used to generate consent. Indeed the unilateral strategy was used as a tool to gain acceptance of the multilateral strategy, as the US explicitly used Special 301 provisions to coerce larger developing countries, such as Korea and Brazil, into accepting the inclusion of IPRs in the ..negotiations...'given a choice between America sanctions or a negotiated multilateral agreement, the TRIPS agreement began to look better'...' (p. 7/8). On pressure, see also Commission on Intellectual Property Rights, Report, id, 'there is sustained pressure on developing countries to increase the levels of IP protection in their own regimes, based on standards in developed countries..'.

Ixvii On why TRIPS handicaps developing countries both economically and politically see Wade $R$., id, p. 4-5 (economically because TRIPS raises prices for these countries, which are only buyers and politically because obligations towards developing countries under TRIPS are unenforceable-'no developing country has taken a developed country to the dispute settlement mechanism for not transferring technology..', p. 5).

Ixviii See above, $b$.

Ixix There can be no intellectual property rights to the texts of judicial decisions, as these are of course not the original creations of the compiler of a legal database. No matter how simple this may sound, there has been extensive litigation in the US by West Publishing (Thomson enterprises-giant publisher company) related to its legal databases (claiming intellectual property rights to their star pagination system etc).

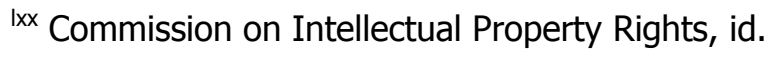

Ixxi Emphasis added.

Ixxii See above, note 49.

Ixxiii Id, p. 11.

Ixxiv Id, p. 12. '..it becomes critical that the existing copyright regime be supplemented by a sui generis system, so that all traditional knowledge databases are protected; this would facilitate the commercialization and trading of such data..'.

Ixxv Id., p. 13. '.. The potential use of this vast and varied genomic data could bring in substantial revenues for the country..'. However, he also notes that the Indian government, in keeping with the norm of facilitating scientific research through open sharing of data, begun making its genomic data public.

Ixxvi Id, p. 23.

Ixxvii Id., p. 24.

Ixxviii On decode and Icelandic genetic information, see next paragraphs.

Ixxix On ownership of legal information in the UK, in general and in connection with the database Directive see Leith, Owning Legal Information, EIPR 2000, 22(8), 359-365.

Ixxx Id, note 49.

Ixxxi Id., note 49.

Ixxxii Note, for example, the case on Mongolian wool, cited by Wade, On the Causes of Increasing World Poverty and Inequality, or Why the Matthew Effect Prevails, New Political Economy, vol. 9, No. 2, June 2004, p. 163. In this case (p. 181), after the break up of the Soviet Union, Mongolia adopted a full-scale liberalization package; people were driven back into agriculture and herding; a special export tax on raw wool was removed, because of threats by the Asian Development Bank and in the end, the Chinese process virtually all of Mongolian wool. This is a case where a country's tangible resources is controlled by another country and which is cited, obviously, as wrong. The same wrongfulness would emerge, had the Chinese 
managed to control, for example, a database with all Mongolian geographic indicators and exclude the Mongolians from it. This would be a case of unjustified control of another country's information commons (intangible resources). Ixxxiii

http://www.mannvernd.is/english/articles/greely

\& king-e/html, letter by Dr. Henry Greely, Professor of Law, Stanford University and Dr. Mary King, Professor, University of Washington.

Ixxxiv Id.

Ixxxv Id. See also Garfinkel, Database Nation, The Death of Privacy in the 21si Century, O'Reilly, 2000, pp. 193-186.

Ixxxvi Garfinkel, id, 194. Note also the comment by the CIPR, id., on traditional knowledge and geographical indications, '...Even if patents are granted for valid inventions derived from genetic resources or traditional knowledge, it may be that the communities that provided such resources or knowledge did not give their informed consent, and no arrangements for sharing any benefits from commercialization were agreed upon...'.

Ixxxvii A partly similar case of immoral appropriation of information in developing countries was the very well known case of the AZT trials on AIDS, by American researchers, in situations where the same trials in the US would be illegal. See Marcia Angell, The Ethics of Clinical Research in the Third World, New England Journal of Medicine, vol. 337, no 12, September 18, 1997 and Lurie P. \& Wolfe $S$., Unethical Trials of Interventions to Reduce Perinatal Transmission of the Human Immunodeficiency Virus in Developing Countries, New England Journal of Medicine, vol. 337, no. 12, September 18, 1997. The trials took place in Sub-Saharan Africa and Thailand and used randomized, placebo-controlled methods to test the effectiveness of interventions in preventing perinatal transmission of human immunodeficiency virus (HIV). All trials were funded either from the US government or from foreign governments-only one was funded by the United Nations Program on AIDS (UNAIDS). The main objection to the trials was that the trial subjects, women form developing countries carrying the HIV virus (and certain to die at some point) were deprived of a therapy known to be effective. Therefore, human subjects were given different protections in the sponsoring countries and in the countries were these trials took place. Annas GJ. Grodin MA, An Apology is Not Enough, Boston Sunday Globe
1997, May 1, Angell M., Ethical Imperialism? Ethics in International Collaborative Clinical Research, New England Journal of Medicine 1988, 319, 1081.,

Ixxxviii On self-defense as justification for a lie see Bok S., Lying: Moral Choice in Public and Private Life, 1983. A lie is, of course, to use another person's legal password as your own, to gain access to a protected database. In an e-mail by Chris Simon, member of the Papersinvited (US company) Team, answering my query why I had, as a legal subscriber to the database 'papersINVITED', only access to the databse fir six times each month, and not constantly, Chris Simon said (22.7.2004): '..the reason we placed a limit of six logins per user per calendar month is because of abuse (creating one login and sharing the same with multiple users) particularly in developing countries (emphasis added). Without such restrictions, quite a few organizational subscribers would not even consider a subscription...'. The annual cost of using the database for me, as an offer, $45 \$$ per year. This is not negligible, even in Greece, as payment for 6 times a month access to one single database for professional reasons. I cannot help but sympathize with researchers from developing countries, who may share a password from time to time-I also think that these people would either share, or not have access altogether (they would not be able to pay these amounts and papaersINVITED is not really losing money, because they would not receive these subscriptions anyway). It is not surprising, then, why it is the developing countries, who engage in such 'abuse'.

Ixxxix Hugenholtz B., Code as Code or the End of Intellectual Property as We Know It, www,ivir.nl, publications, p.10. Hugenholtz interestingly cites Pr. Phillips, who compares the extinction of the public domain to the whittling away of the mighty rainforests of South-America (again, probably due to Western policies).

xc See for example Branscomb A., Who Owns Information? From Privacy to Public Access, Basic Books, 1994.

xci On serious and detailed doubts whether globalization is, as claimed, reducing poverty and inequality see Wade $R$., Is Globalization Reducing Poverty and Inequality? World Development Vol. Xx, No X, pp. www-www, 2004, 2004, on file with the author (see also http://www.elsevier.com/locate/worlddev), 
'...world income distribution has become rapidly more unequal, when incomes are measured at market exchange rates and expressed in US dollars; world PPP-income polarization has increased, with polarization measured as richest to poorest decile; between-country world PPPincome inequality has been constant or falling since around 1980, with countries weighed by population; several serious studies find that world PPP-income inequality has increased over a period within the past two to three decades, taking account of both between-and within-country distributions; pay inequality within countries was sable or declining from the early 1960 's to 1980 1982, then sharply and continuously increased toward greater inequality in manufacturing pay worldwide...absolute income gaps are widening and will continue to do so for decades...Aside from the moral case against it, inequality creates a kind of society that even crusty conservatives hate to live, unsafe and unpleasant....higher income inequality within countries goes with higher poverty....slower economic growth, higher unemployment and ..higher crime...'. See also Wade $R$. , On the Causes of Increasing World Poverty and Inequality, or Why the Matthew Effect Prevails, New Political Economy, vol. 9, No. 2, June 2004.

xcii And perhaps in the end, hinders the interests of the powerful nations as well. See Wade $R_{\text {., }}$ Globalization, id., '..the interests of the rich and powerful should objectively line up in favor of greater equity in the world at large, because some of the effects of widening inequality may contaminate their lives and the lives of their children..'. 